\title{
部分有効電力検出法による高温超電導及び 交流用金属超電導コイルのクエンチ検出
}

\author{
学生員 七戸 希 (名古屋工業大学) \\ 正員中村 光一 (名古屋工業大学) \\ Quench Detection of HTS Coil and AC LTS Coil \\ by Partial Active Power Detecting Method \\ Nozomu Nanato, Student member, Koichi Nakamura, Member \\ (Nagoya Institute of Technology)
}

\begin{abstract}
Excessive ohmic heating may damage superconducting wires when a quench occurs in a superconducting coil and hence it is necessary to detect the quench as fast as possible in order to protect the superconducting coil. We have proposed a new quench detecting method, which can detect an active power after a quench with high precision.

In this paper, in order to investigate the usefulness of the proposed method for HTS (High Temperature Superconducting) coils, quench detection tests of a small HTS coil are carried out and the results are presented. In general, HTS coils are not necessarily self-protective because quench propagation velocities in high Tc superconductors are slower than those in low Tc superconductors. Therefore a quench detecting method with high precision and fast response is required for HTS coils. Through the quench detection tests of a sma11 Ag/Bi-2223 HTS coil, the usefulness of the proposed method is investigated. In addition, through the off-line quench detection tests of AC LTS (Low Temperature Superconducting) coils by the numerical simulation, the usefulness of the proposed method for AC LTS coils is also discussed.
\end{abstract}

キーワード: クエンチ検出, 部分有効電力検出法, 高温超電導コイル, 交流用金属超電導コイル

Keywords: quench detection, partial active power detecting method, HTS coil, AC LTS coil

\section{1. まえがき}

超電導コイルにクエンチが生じると巻線抵抗で過大な発 熱が起こり超電導線の焼損・劣化等が生じる可能性がある ため, クエンチを早期に検出しコイルを保護する技術注不 可欠である。そこで著者らは精度の高い超電導コイルのク エンチ検出法として「部分有効電力検出法」を提案し，試 験用 $\mathrm{NbTi}$ 金属超電導小コイルを用いたクエンチ検出実験

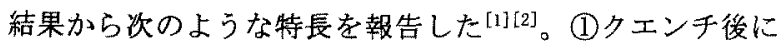
生じた巻線抵抗で消費される有効電力を検出することでク エンチ検出を行う，(2)ノイズ（電磁誘導ノイズなど）に対 する耐性があり，ノイズによるクエンチの誤判定を回避で きる，(3)交流・直流どちらを通電している場合でもクエン チ検出が可能である。
上記報告では，金属超電導小コイルで提案法の有効性を 確認したが，本論文では，オンラインクエンチ検出害験に よる高温超電導コイルに対する提案法の有勃性検証及び才 フライン数值シミュレーションによる交流用金属超電導コ イルに対する提案法の原理検証を行う。近年高温超電導線 材, 特に $\mathrm{Ag} / \mathrm{Bi}-2223$ テープ線材の開発が進んで㧍り,コイ ルの試作も行われるようになった。高温超電導線材（コイ ル）では金属超電導コイルに比べてクエンチ伝播速度が遅 いためクエンチが局所的に起こりやすくクエンチ後の上昇 温度も大きくなる ${ }^{[3]}$ 。よって，より速く確実にクエンチを 㭘出する必要がある。そこで提案法を用いて, $\mathrm{Ag} / \mathrm{Bi}-2223$ 高温超電導小コイルのクエンチ検出実験を行い, その結果 を報告する。実験では，単相 PWM (Pulse Width Modulation) インバータからクエンチ電流以上の振幅を持った様々な周 
波数の正弦波電流を突発的に数サイクル通電した場合とヒ 一タを用いた場合においてオンラインでクエンチ梠出を行 い，上記課題について検証した。また，交流用金属超電導 コイルに対しては,クエンチ波形データ（クエンチ前後の コイル雨端電圧, 電流波形) を用いたオフライン数值シミ ュレーションにより，提案法の原理険証を行った。以下の 各章を通じてこれら実験結果に関する検討を行う。

\section{2. 部分有効電力検出法}

図 1 に部分有效電力検出法の説明図を示す。コイルの両 端および中間に電圧端子を取り付け，電圧 $v_{1}, v_{2} お$ よび電 流 $i$ を検出する（文献[1] [2]に比し，クエンチ検出回路に 入力される電圧 $v_{1}$ をさげるために同図のように電圧を検出 することとした)。

ここで,

$$
P=\left(v_{1}+v_{2}\right) i \cdots \ldots(1)
$$

と定義すると，超電導状態において

$P=0 . \ldots \ldots \ldots(2)$

となり，常電導状態（クエンチ時）において

$$
P=\left(r_{1}-r_{2}\right) i^{2} \ldots \ldots \ldots(3)
$$

となるため，(2)，(3)式から理論的には $P$ (瞬時有効電力) を観測することでクエンチを検出できることがわかる。し

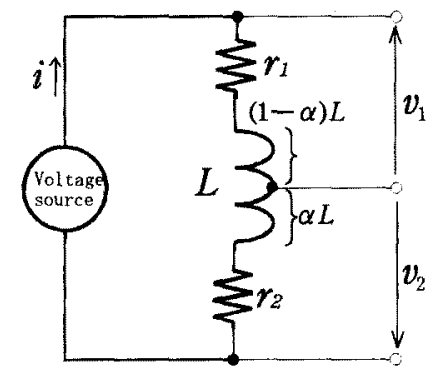

$r_{1}, r_{2}$ : Winding resistance emerged ${ }^{2}$ th the quench $\alpha$ : Constant (=0.5) , L: Inductance

\section{図 1 部分有効電力検出法説明図}

Fig. 1. Explanation for a partial active power detecting method.

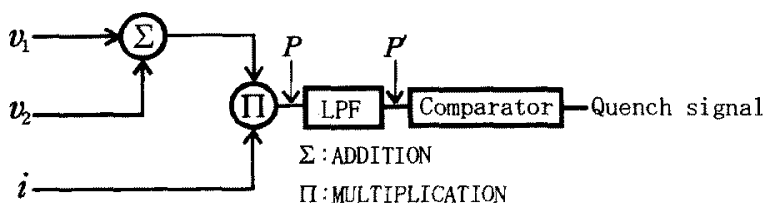

図 2 検出回路のブロック線図

Fig. 2. A block diagram of the quench detector.
かしながら，実際上はノイズ（電磁誘導ノイズ等）の重畳 により，超電導状態においてもPは0にならず，クエンチ が譟判定される可能性がある。そこで，(3)式に直流成分が 含まれている（Pが電流自乗に比例することに依る）こと に着目し，LPF (low pass filter) を用いてノイズを除去 する。すなわち，LPFによってノイズは減衰するが直流成 分は减衰せず通過するため $\mathrm{S} / \mathrm{N}$ 比の高い信号を得ることが でき，精度の高いクエンチ検出が可能となる。Pをフイル タリングしたものをPと定義し，二れを部分有効電力と呼 ぶこととしクエンチ検出パラメータとして用いる。なお, ここでは $\alpha=0.5$ の場合を例に説明したが, 必ずしもそうで ある必要はない。 $\alpha \neq 0.5$ のときは， $v_{1} も し く は ~ v_{2}$ に適切 な係数を乗じることで(1) 式右辺の括弧内（電圧の和）が 0 になるように調整すればよいけ1。

図 2 にクエンチ検出回路のブロック線図を示す。この回 路はオペアンプ等の電子回路で構成され最も簡易で外乱の 影響を受けにくい構造となるように設計した。同図に示さ れた過程でPが算出され，クエンチ判定は比較器で閾值比 較によりなされる。なお，以下の寒験では，LPF の遮断周 波数は $10 \mathrm{~Hz}$ (一次) である。

\section{3. $\mathrm{Ag} / \mathrm{Bi}-2223$ 高温超電導コイルのクエンチ検出}

$<3.1>$ 実験概要 高温超電導コイルのクエンチ検 出実験には図 3 に示す $\mathrm{Ag} / \mathrm{Bi}-2223$ 高温超電導小コイル ((株) 昭和電線電䌮製)を用いた。その諸元を表 1 に示す。 このコイルは二層構造の二つのコイルがグレーディング (コイル中心が同じ位置になるように配置)された構造に なっており，内側コイルの電圧が $v_{1}$, 外側コイルの電圧が $v_{2}$ に相当するように電圧端子を設けた。なおコイルは液体 室素浸清椧却されている。図 4 に示す単相 PWM インバータ からクエンチ電流以上の振幅を持った様々な周波数の正弦 波電流が突発的に通電されるように電圧を印加した場合お よびこイル（内側コイル）に取り付けたヒ一タ（10 $\mathrm{mm}$ 100mm, 0.1W）を使用した場合の二通りでクエンチを起こし た。なお，ヒータを用いた実験のときには，差分法（ブリ ッジ回路による電圧差分から抵抗性電圧を検出するクエン 于検出法） [4] と提案法との比較を行うために，差分電圧 $\left(v_{1}+v_{2}\right.$ に相当) の観測も同時に行った。

<3.2> 実験結果 図 5 に過電流によるクエンチ実 験結果の 4 例を示す。これらは, 同図 (a)から (d) の順に $30 \mathrm{~Hz}$ から $10 \mathrm{~Hz}$ きざみで $60 \mathrm{~Hz}$ までの周波数を持った電流を通電 した場合に掞ける結果である。電流波形にひずみが生じて いるのは，乫発的に電压を印加したことによる過渡状態(誘 遒成分）の影響である。いずれの場合においてもPはクエ ンチ後急激に変化しており，明確にクエンチが検出されて いる。P壮クンチ後下向きに変化していることから，ク エンチは外側コイルで生じている。本実験の場合，インバ 一タによるスイッチングノイズが多量に電圧波形 $v_{1}, v_{2}$ に 混入しておりかつクエンチ直後にコイルで消費される有効 電力も数 $\mathrm{mW}$ と微小であったが, P’はほとんどノイズを含ま 


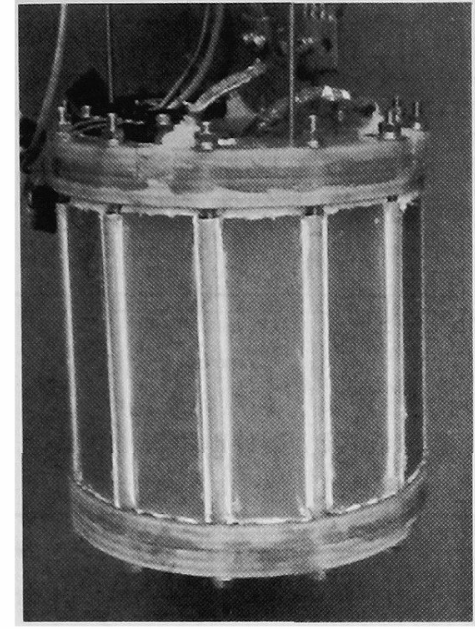

図 $3 \mathrm{Ag} / \mathrm{Bi}-2223$ 高温超電導コイルの外観

Fig. 3. Photograph of Ag/Bi-2223 HTS coil.

表 $1 \mathrm{Ag} / \mathrm{Bi}-2223$ 高温超電導コイルの諸元

Table 1. Specifications of Ag/Bi-2223 HTS coil.

\begin{tabular}{|c|c|}
\hline \multicolumn{2}{|c|}{ Wire } \\
\hline Width & $1.5 \mathrm{~mm}$ \\
\hline Thickness & $0.2 \mathrm{~mm}$ \\
\hline Ratio of silver & 3.5 \\
\hline Filament number & 37 \\
\hline Critical temperature & $109.2 \mathrm{~K}$ \\
\hline Critical current $(1 \mu \mathrm{V} / \mathrm{cm})$ at $77 \mathrm{~K}$ & $6.9 \mathrm{~A}$ \\
\hline \multicolumn{2}{|c|}{$\begin{array}{ll}\text { Inner Coil } \\
\end{array}$} \\
\hline Inner diameter & $\phi 113.7 \mathrm{~mm}$ \\
\hline Outer diameter & $\phi 115.7 \mathrm{~mm}$ \\
\hline Height & 106. $0 \mathrm{~mm}$ \\
\hline Number of turns & 104 \\
\hline Inductance & $0.9 \mathrm{mH}$ \\
\hline \multicolumn{2}{|c|}{ Outer Coil } \\
\hline Inner diameter & $\phi 117.4 \mathrm{~mm}$ \\
\hline Outer diameter & $\phi 119.3 \mathrm{~mm}$ \\
\hline Height & $104.2 \mathrm{~mm}$ \\
\hline Number of turns & 100 \\
\hline Inductance & $0.9 \mathrm{mH}$ \\
\hline \multicolumn{2}{|c|}{ Coil } \\
\hline Inductance & 3. $5 \mathrm{mH}$ \\
\hline
\end{tabular}

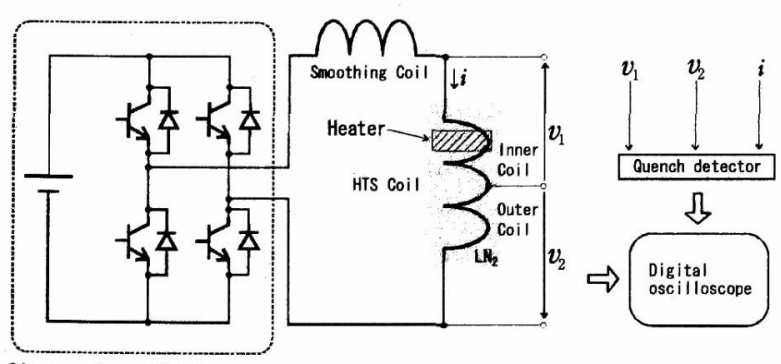

Single phase Pum inverter

図 4 実験装置

Fig. 4. Experimental setup.

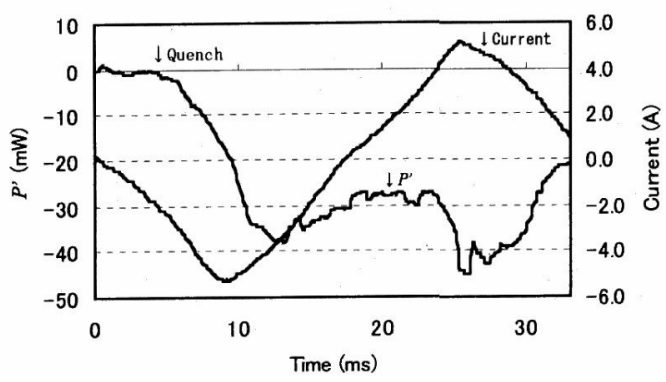

(a) $30 \mathrm{~Hz}$

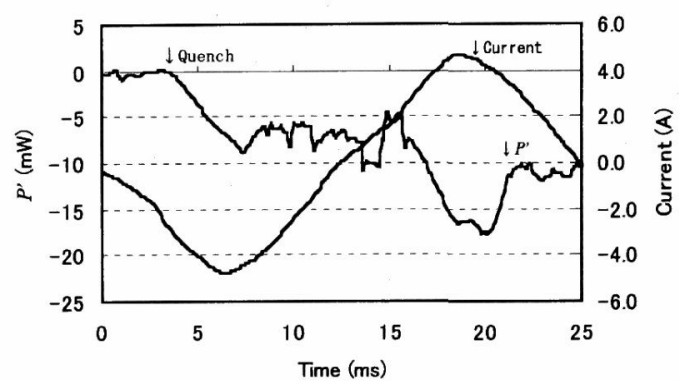

(b) $40 \mathrm{~Hz}$

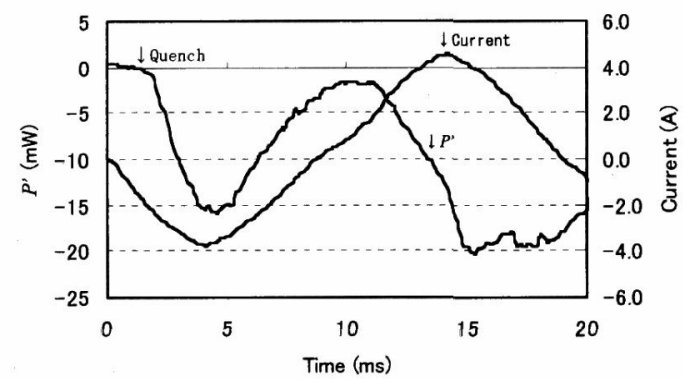

(c) $50 \mathrm{~Hz}$

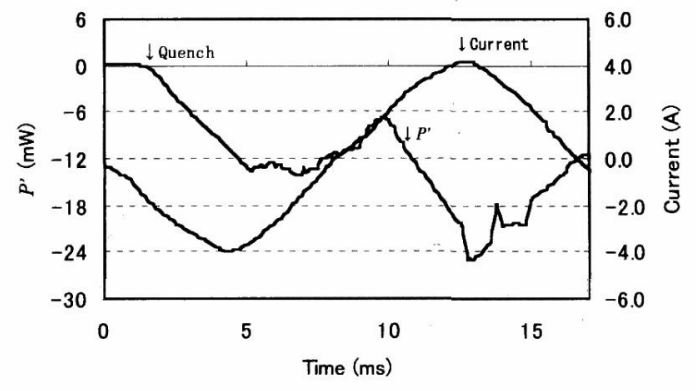

(d) $60 \mathrm{~Hz}$

図 5 過電流時の高温超電導コイルの クエンチ検出実験結果

Fig. 5. Experimental results of the quench detection of a HTS coil in the over current. 
ず高いS/N 比を持った信号として観測でき，その検出の精 度は通電電流周波数に依存することもなかった。また，本 実験から, 使用した高温超電導コイルのクエンチ電流は $2 A$ 前後であったが周波数によって多少の差異を示すことが観 測された。交流損失などの要因が考えられるが, 本論文の 主目的はクエンチ検出であるため,ここでは事実だけを述 べることとし今後の検討事項としたい。

次に, 図 6 にヒータを用いた場合における実験結果を示 す。同図 (a)，(b) は直流 $2 \mathrm{~A}$ を通電したときの実験結果であ る。ヒータ投入後，(a)からクエンチ後に生じた抵抗が微小 であったため電流はほとんど減衰していないことがわかる が，(b)よりP隐激に立ち上がっておりクエンチが検出 されていることがわかる。同図(c)，(d) は $60 \mathrm{~Hz}, 1.4$ Apeak の交流電流を通電したときの塞験結果である。(a)，(b)と 同様，クエンチ後に生じた抵抗は微小であるが，クエンチ は明確に検出されていることがわかる。図 4 に示すように， ヒータは内側コイルに取り付けられているため, クエンチ 後P圤向きに変化しており, 内側コイルでクエンチが生 じたことを示している。図 5,6 から提案法は高温超電導小 コイルのクエンチ検出に有効であることが予想される。な お，本実験に用いた高温超電導コイルに対するクエンチ検 出回路の閾値は，様々な周波数の実験結果からコイル保護 に十分なクエンチ検出時間を見込める $\pm 5 \mathrm{~mW}$ と経験的に設 定した。

$<3.3>$ 差分法との比較提案法と同様に電気的に クエンチを検出する手法として差分法がある。電気的クエ ンチ検出は応答が速くかつ簡単なシステムで実現できると いう利点があり，差分法は信頼性の高い検出法として一般 的に用いられている。本節ではその差分法との比較検討を 行うことで提案法の有効性を検証する。

図 7 に前節のヒータ実験（図 6）のときに観測した差分 電圧を示す。同図 (a) は直流電流通電時の差分電圧である。 差分電压はクエンチに伴って立ち上がりを示しているが, 本実験ではインバータから多量のスイッチングノイズが発 生しているため, 多量のノイズが差分電圧に混入しており, $\mathrm{S} / \mathrm{N}$ 比が提案法に比べ低い信号となっている。また, 差分 電圧の立ち上がりの大きさもP㫐比で緩やかである（差 分電圧は電流に比例し $P$ は電流自乗に比例することに依 る) ため, フィル夕処理等によって差分電圧のノイズを除 去したとしても，提案法はより速くクエンチを検出できる と考えられる。同図(b) は交流電流通電時の差分電圧である。 クエンチに伴い抵抗性交流電圧が発生しているが, 同図 (a) と同様多量のノイズが混入している。また，信号が交流で あるため, フィルタ処理をするとノイズとともにクエンチ 信号（抵抗性交流電圧）も減衰するのでフィルタ処理によ るノイズ除去は難しい。よって抵抗性交流電圧を検出する にはロックインアンプを用いて同期信号として検出するの が一般的であろう。しかしながら提案法の場合は，瞬時有 効電力 ( (3) 式) をクエンチ検出パラメータとして用いてお り，そのクエンチ信号は直流成分を持っているため，フィ

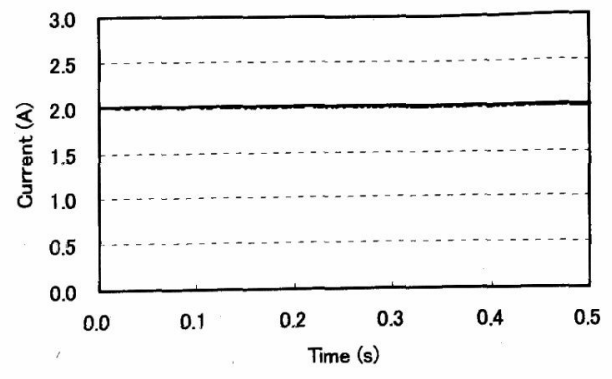

(a) DC current (2A)

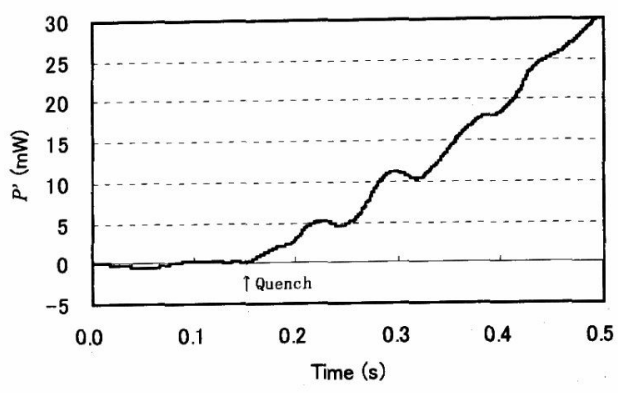

(b) $P^{\prime}$ (DC)

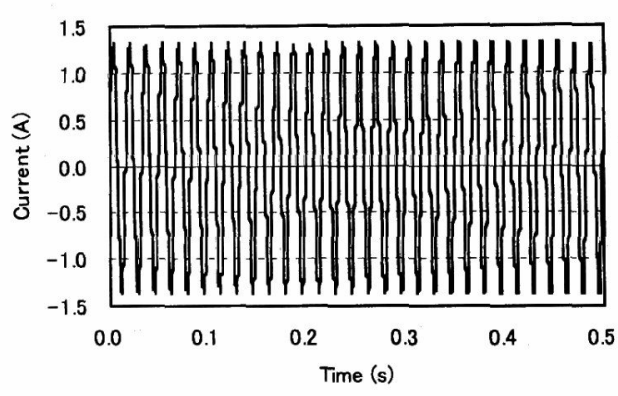

(c) AC current (1.4Apeak, 60Hz)

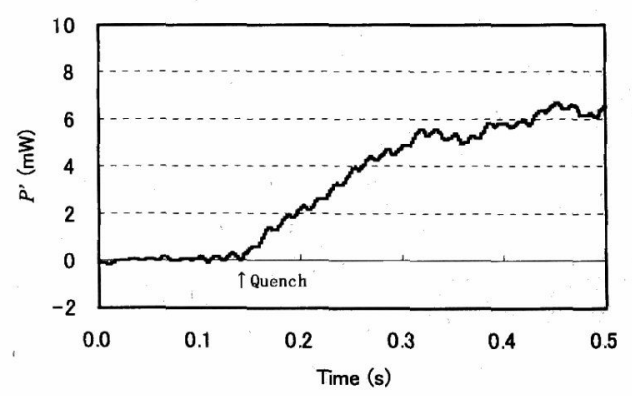

(d) $P^{\prime}$ (AC)

図 6 ヒータ使用時の高温超電導コイルの クエンチ検出実験結果

Fig. 6. Experimental results of the quench detection of a HTS coil in the use of the heater. 


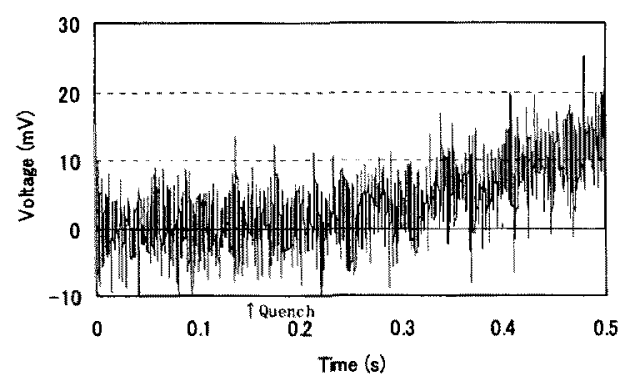

(a) DC

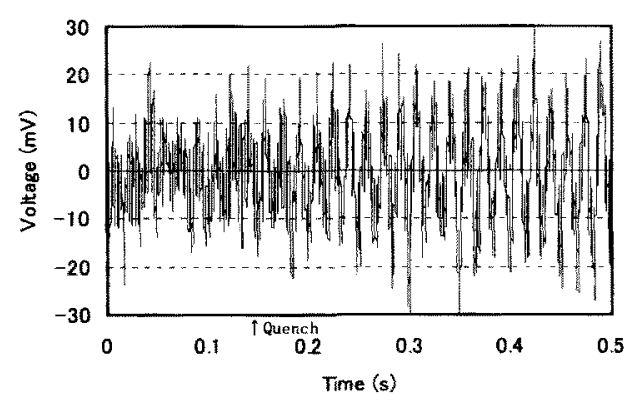

(b) $\mathrm{AC}$

\section{図 7 差分電圧}

Fig. 7. Resistive voltage signals.

ルタ好理によって容易にノイズを除去できる，すなわち直 流通電時と同じ処理でクエンチ検出できる。これらの結果 から，提案法は一般的に信頼性が高いとされている差分法 に比へて耐ノイズ性があり，検出速度が速く，汎用性のあ るクエンチ検出ができることが期待できる。

本章および文献[1][2]のオンラインクエン千検出実験結 果から，中間端子を取り付けることのできるコイル（直流 用コイル，小型コイルなど）であれば提案法を用いること で速く確実なクエンチ検出が籣易なシステムで実現可能で あることが予想される。

\section{4. 交流用金属超電導コイルのクエンチ検出}

\section{〈4. 1> 数值シミュレーションによる部分有効電力换} 出法の原理検証 表 2 に三種の交流用金属超電導コイル

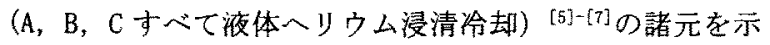
す。これらのコイルには中間端子が設けられていないため， ここではクエンチ波形データ（クエンチ前後のコイル両端 電圧, 電流波形) を用いて，これらのコイルに中間端子が 設けられていることを仮定したオフライン数值シミュレー ションによるクエンチ検出から提案法の交流用金属超電導 コイルに対する有効性について検討寸る。提案法は瞬時皮 相電力中の交流損失及び無効電力を抑制しクエンチ後のコ イル巻線抵抗で消費される有效電力のみを検出する手法で
表 2 交流用金属超電導コイルの諸元

Table 2. Specifications of AC LTS coils.

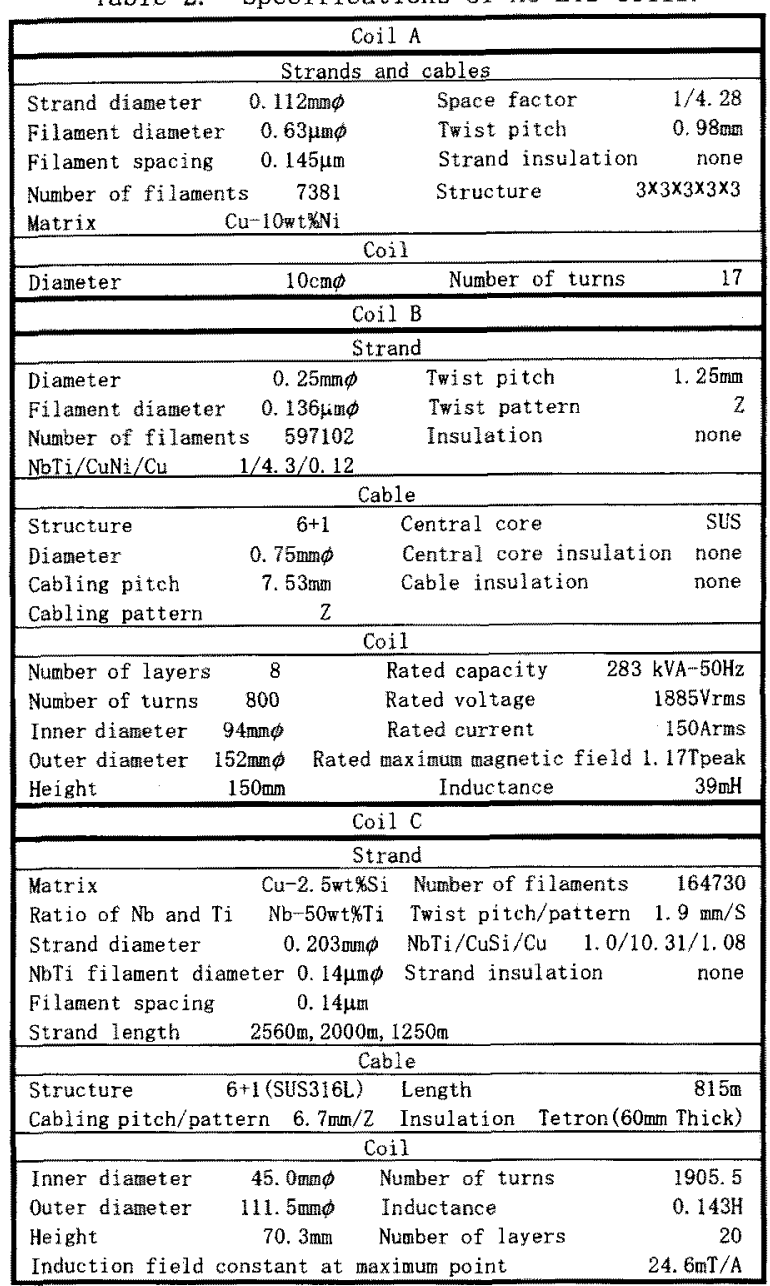

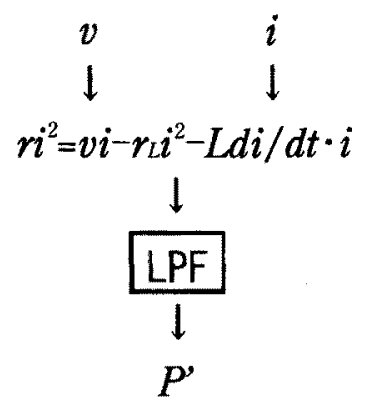

図8 数值シミュレーションのフローチャート

Fig. 8. A flow chart of the numerical simulation.

ある。その際に提案法では中間端子を使用するが，上述の ように，表 2 に示したコイルは中間端子を持っていないの で図 8に示寸数值シミュレーションにより提案法を模擬し た。すおち，

1. コイル両端電圧 $v$ と通電電流 $i$ を乗じて瞬時皮相電力 を求める 
2. 交流損失等価抵抗 $\boldsymbol{r}_{L}$ をタエンチ前の平均電力 $\left(r_{L} \int_{0}^{T} i^{2} d t\right)$ 力ら求める（ $\mathrm{T}:$ 電流周期 $)$

3. 電流微分, インダクタンスおよび電流の積から無効電 力を求める

4. 1 から 2 と 3 を減じて巻線抵抗 $r$ で消費される有効電 力を求め,フィル夕処理 $(10 \mathrm{~Hz})$ する

という過程で，三種のコイルに対する提案法の適用を模擬 した。この数值シミュレーションでは(3)式のような差分が 算出されないため瑗密には提案法を適用した場合とは異な るが，クエンチが起こった瞬間に生じる抵抗は(3)式の $r_{1}$ もしくは $r_{2}$ あどちらかであることを考慮すれば，クエンチ 直後であれば差分を考慮する必要はない。よってクエンチ 検出の場合のように，クエンチ直後の波形を取り扱うこと に関してはこの数值シミュレーションは提案法の模擬とし て問題はない。

図 9，10にシミュレーション結果を示す。図 9 は各コイ ルのクエンチ前後の電流・電圧波形である。図 10 は図 9

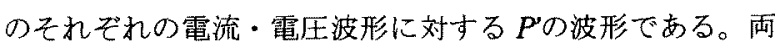
図において (a) はコイルA（電流周波数 $48 \mathrm{~Hz}$ )，(b) はコイル B (同 $53.04 \mathrm{~Hz}) ，(\mathrm{c})$ はコイルCの実験結果（同 $69.03 \mathrm{~Hz}$ )

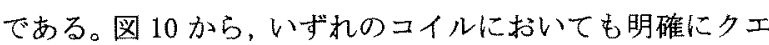

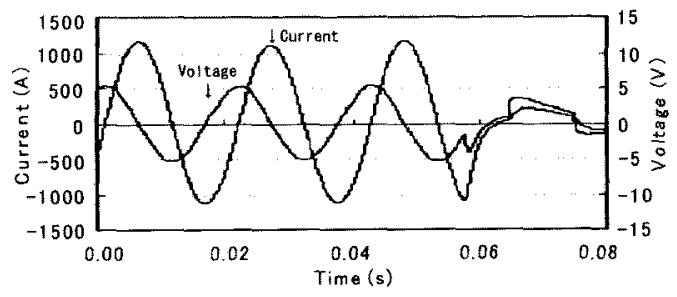

(a) Coil A (48Hz)

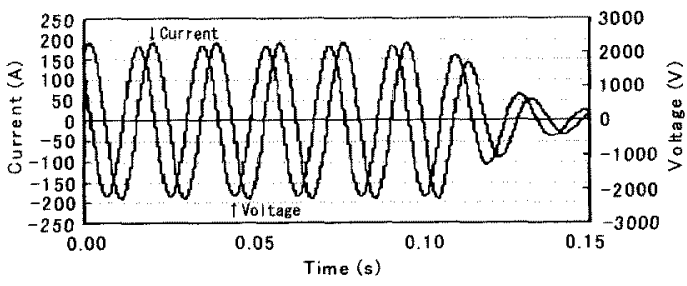

(b) Coil B $(53.04 \mathrm{~Hz})$

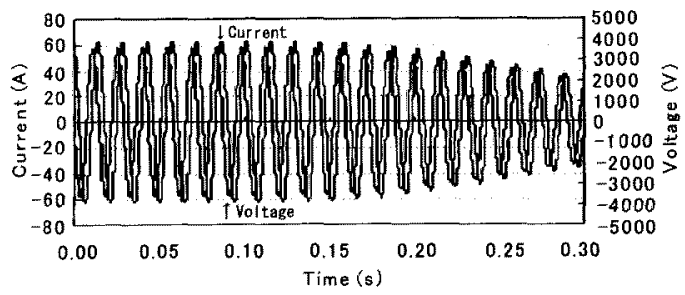

(c) Coil C $(69,03 \mathrm{~Hz})$

図 9 電流・電圧波形

Fig. 9. Waveforms of the current and voltage.
ンチが検出されていることがわかる。また，各コイルの結 果を比較するとP’立ち上がり方に違いが生じている。こ れはコイル巻線に用いられている線材の銅比と通電電流值 の違いによるものである。 $\mathrm{A} \rightarrow \mathrm{B} \rightarrow \mathrm{C}$ の順で銅比が大きくな り電流值が小さくなっているため, 順に線材の抵抗が小さ くかつ常電導伝播速度が達くなり ${ }^{[8]}$, それに伴って電流の 減衰の仕方が緩や引沈なる。そのためPの立ち上がりも緩 やかになっているのである。したがって，銅比が高いほど クエンチ検出が遅れることになる。しかし逆に，銅比が高 ければコイルの安定度が高く（急激な常電導転移を起こさ ない）なり，急激な温度上昇が生じにくくなることを考慮 すれば，この遅れは問題ではない。このことから，表 2 の コイルに中間端子を取り付ければ提案法によりクエンチ険 出が可能であると予想される。

\section{5. まとめ}

本論文では新しいクエンチ検出法として提案した部分有 効電力検出法による $\mathrm{Ag} / \mathrm{Bi}-2223$ 高温超電導小コイルのオ ンラインクエンチ検出実験による提案法の有効性検証およ び三種の交流用金属超電導コイルを用いたオフライン数值 シミュレーションによる提案法の原理検証を行った。高温 超電導コイルの実験結果から，クエンチ後に生じる有効電

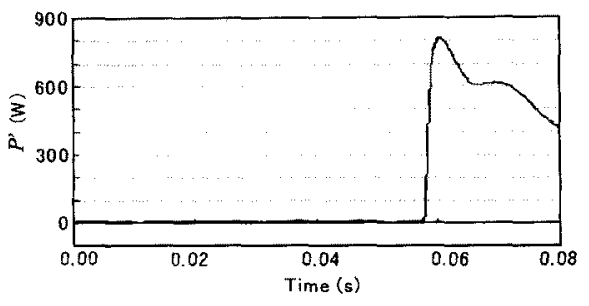

(a) Coil A (48Hz)

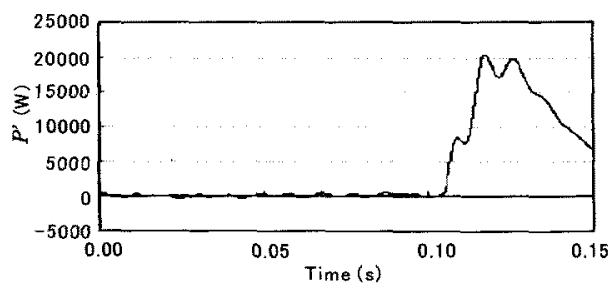

(b) Coi1 B $(53.04 \mathrm{~Hz})$

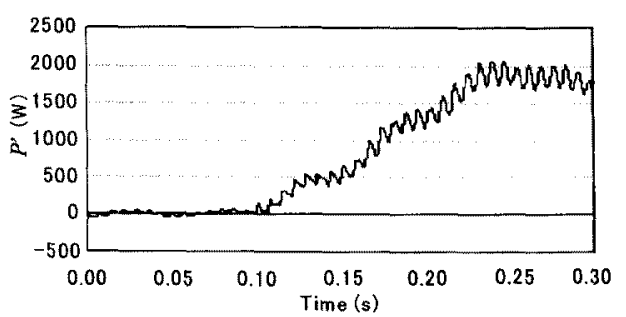

(c) $\operatorname{Coil~C}(69.03 \mathrm{~Hz})$

図 $10 \quad P$ 波形

Fig. 10. Waveforms of $P^{\prime}$. 
力が微小であり且つインバータからスイッチングノイズが 多量に発生している環境でも高い $\mathrm{S} / \mathrm{N}$ 比を持ったクエンチ 信号を得ることができ，その特性は電流の振幅，周波数に も依存しないため, 提案法は高精度且つ汎用性のある手法 であると言える。またオフライン数值シミュレーションに よる交流用金属超電導コイルのクエンチ検出結果から, 中 間端子を取り付ければ提案法はこれらのコイルに対しても 有効であることが予想される。これらより，提案法は中間 端子を取り付けることのできるコイルであればどのような コイル・運転状況に対しても精度よくクエンチ検出可能で あることが期待できる。

しかしながら，一般的には交流用コイル (大型, 実用機) では電圧対策から中間端子を設けることやコイルから多く の計測線を引き出すことは難しい ${ }^{[4]}$ 。本文中の数值シミュ レーションがオンライン化できれば中間端子を設けずに有 効電力検出できるが，交流損失等価抵抗は結果から得たパ ラメータであり, 微分演算はノイズ等の外乱を拡大するた め, これをオンラインシステムとして構築することは難し いと考えられる。よって今後は中間端子を必要としない電 気的クエンチ検出について検討していく予定である。

謝辞 最後に, 高温超電導コイルの作製をしていただき ました（株）昭和電線電綎の大谷望氏，データの提供等し ていただきました電力中央研究所の鳥居慎治氏, 秋田調氏,

（株）東芝の関係各位, 研究にご協力いただきました名古 屋工業大学システムマネジメント工学科助教授の瓶飼裕之 氏, 同電気情報工学専攻修士課程 2 年の柳下正弘君に謝意 を表します。

本研究の一部は科学研究費補助金(特別研究員奨励費,

課題番号 2053）によるものであり謝意を表します。

(平成 12 年 11 月 13 日受付, 平成 13 年 2 月 14 日再受付)

\section{文献}

[1] 七戸，川田，中村：“超電導コイルクエンチ検出のための部分有効電 力検出法の提案”, 電学論 B, 119 巻 11 号, pp. 1174-1180 (1999)

（2］柳下，他：“DSP を用いた部分有効電力検出法による超電導コイルのリ アルタイムクエンチ検出”, 高速信号処理応用技術学会誌, 第 2 巻 4 号, pp. 11-16 (1999)

[3] R. H. Bellis and Y. Iwasa: "Quench propagation in high Tc superconductors, " Cryogenics, vol. 34, No. 2, pp. 129-144 (1994)

４］低温工学協会：“超伝導・低温工学ハンドブック”，オーム社, p. 603

[5] 鳥居, 他: “ $1 \mathrm{kA}$ 級トリプレックス交流超電導然り線導体の特性”, 電 気学会静止器 - 回転機合同研究会資料, SA-92-58/RM-92-121 (京都), pp. 113-118, 1992 年 12 月

[6] 鳥居, 他: “エポキシ充填固定交流超央尊巻線の通電特性”, 電学論 B, 116 巻 7 号, pp. 798-803 (1996)

[7] H. Kasahara, S. Akita and S. Torii : "Development of 100kVA AC Superconducting Coil Using NbTi Cables with a CuSi Alloy Matrix" , IEEE Trans. Magn. vol. 32, No. 4, July, pp. 2751-2755 (1996)

[8］電気学会：“超電導工学 (改訂版)”, オーム社, pp. 90-93（1988）

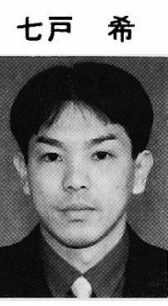

(学生員) 1975年4月6日生まれ。2000年3 月名古屋工業大学大学院工学研究科電気情 報工学専攻博士前期課程修了, 同年4月同後 期課程入学, 現在に至る。超電導コイルの クエンチ現象に関する研究に従事。平成 12 年 4 月 15 年 3 月, 日本学術振與会特別研究 員。低温工学協会, 高速信号処理応用技術 学会の各会員。

中村 光一（正員）1942年3月7日生まれ。1965年3月

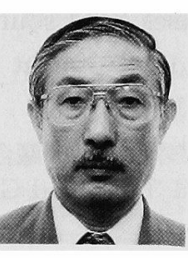
名古屋工業大学工学部電気工学科卒業。 1966年同助手。1988年同助教授, 1997年同 システムマネジメント工学科教授, 現在に 至る。1983〜84年クラークソン大学客員研 究員。工学博士。電力系統解析, 高温超電 導の電力応用, ロケット誘雷に関する研 究に従事。1982年電気学会論文賞, 1989年電気学会進歩賞, 1998年日本大気電気学会学術研究賞。日本大気電気学会, 電気設備学会, 低温工学協会, 高速信号処理応用技術学会, IEEEの各会員。 